\title{
Effect of incorporation of nutraceutical capsule waste of safflower oil in the mechanical characteristics of corn starch films
}

\author{
Camila de CAMPO ${ }^{1}$, Tania Maria Haas COSTA $^{1,2}$, Alessandro de Oliveira RIOS ${ }^{1}$, Simone Hickmann FLÔRES ${ }^{1 *}$
}

\begin{abstract}
Biodegradable films blends made of safflower oil nutraceutical capsules waste: corn starch (20:4, 30:4, 40:4 and 50:4) were prepared. The objective of this study was to evaluate the influence of addition of different concentrations of safflower oil nutraceutical capsule waste in the mechanical properties (tensile strength, elongation at break, Young's modulus) and thickness of corn starch films. A decrease in tensile strength and Young's modulus and an increase in elongation at break were observed with the increase in the content of the nutraceutical capsule waste. The results showed that the blends of safflower oil capsules waste-corn starch films demonstrated promising characteristics to form biodegradable films with different mechanical characteristics.
\end{abstract}

Keywords: food packaging; biodegradable films; gelatin; blends.

Practical Application: This work showed one alternative for the reuse of the wastes of nutraceutical capsules as a material to produce biodegradable films, reducing environmental and economic problems. The nutraceutical capsules waste can be used to produce food packaging with desirable mechanical properties, helping to improve these characteristics in corn starch films.

\section{Introduction}

The environmental damage of non-biodegradable plastic material wastes is a worldwide concern. The interest in films produced from natural macromolecules is growing because of the current demand of consumers for more natural and environmentally friendly packaging materials (Emiroğlu et al., 2010; Bodini et al., 2013). Polymers obtained from renewable resources or valorization of agro-industrial wastes and by-products are regarded as a good alternative.

Materials based on polysaccharides are environmentally friendly because they can degrade without leaving behind ecologically harmful residues. Due to this, polysaccharides are considered as a good alternative for biodegradable films because they are found abundantly in nature and have been regarded as structural materials (Simkovic, 2013). Starch is the most widely employed polysaccharide for film production because it is naturally abundant, present inherent biodegradability, is low cost and has a desirable performance; being corn, it is the commercial starch source most commonly found in the world (Mali et al., 2004). When converted into a biodegradable material, starch is an interesting alternative for synthetic polymers in applications where long-term durability is not needed and rapid degradation is an advantage (Flieger et al., 2003). However, the use of starch is limited as packaging due to low resistance to mechanical stress and sensibility to moisture (Wu et al., 2013).

One effective strategy to address these issues is to elaborate biodegradable films by association of starch with other biopolymers exhibiting film forming properties and derived from renewable sources. Biodegradable films can be elaborated from protein, polysaccharides, lipids or a combination of one or more of these components (Cao et al., 2007). Blending of biopolymers is a promising strategy to improve the properties of edible films and coatings. Biocomposites films have been prepared by various methods and are usually composed of two or three biopolymers (Famá et al., 2009).

Among the biopolymer materials, proteins from different sources have been used for the development of biodegradable films due to their relative abundance and good film-forming ability (Ou et al., 2005; Prodpran et al., 2007).

In recent years, there is a growing interest in nutraceuticals, which provide health benefits and are alternative to modern medicine. Nutrients, herbals and dietary supplements are major constituents of nutraceuticals, which make them essential in maintaining health. They act against various disease conditions and thus promote the quality of life. The nutraceutical industry has grown in recent years as the growing consumer interest in health-enhancing foods. Nevertheless, the nutraceutical capsules industry causes a large amount of waste as they are discarded in the environment and contribute greatly to pollution and generate high costs for disposal. The use of this waste in other applications is interesting to the nutraceutical industry because it would reduce environmental problems as well as the costs generated by waste treatment. Due to its composition (glycerol, gelatin, and water), the nutraceutical capsule manufacture waste could be used as an adequate source for the preparation of biodegradable films with desirable characteristics. 
The objective of this study was to develop biodegradable films blends of safflower oil capsules waste and corn starch in different proportions (20:4, 30:4, 40:4 and 50:4) and to characterize their mechanical properties and thickness.

\section{Materials and methods}

\subsection{Materials}

Safflower oil capsule waste was provided by the Laboratory Chemical Pharmaceutical Tiaraju, located in Santo Angelo - RS, from the manufacture of food-grade gelatin capsules. The wastes are composed of water $(30 \%)$, glycerin $(21.8 \%)$ and gelatin $(48.2 \%)$. For the production of films, the waste from safflower oil capsules was used. Corn starch (Maizena ${ }^{\circledR}$ ) was obtained from a local market.

\subsection{Preparation of blend films from corn starch and safflower oil capsule waste}

The films were prepared according to the casting technique. The film formation solutions were prepared using blends of safflower oil capsule waste (gelatin, glycerol and water) and corn starch. Different ratios of safflower oil capsule waste: corn starch (20:4, 30:4, 40:4 and 50:4) were elaborated. A solution of (4\%, $\mathrm{w} / \mathrm{v})$ corn starch was prepared: $4 \mathrm{~g}$ of corn starch was dissolved in $50 \mathrm{~mL}$ of distilled water and heated in a water bath at $80^{\circ} \mathrm{C}$ with magnetic stirring for $20 \mathrm{~min}$ until completely gelatinized. The nutraceutical capsule waste film-forming solution with different proportions were prepared, by mixing a $20 \mathrm{~g}, 30 \mathrm{~g}$, $40 \mathrm{~g}$, and $50 \mathrm{~g}$ of waste from safflower oil capsules, respectively, in $50 \mathrm{~mL}$ of water (conditions defined according to preliminary tests) in a water bath (Model 752A, Mark Fisatom) under constant stirring to melt the network at $60^{\circ} \mathrm{C}$ for $30 \mathrm{~min}$.

The waste solution was added to gelatinized corn starch at $60{ }^{\circ} \mathrm{C}$ (to achieve the desired proportions) and stirring was continued for $15 \mathrm{~min}$, to obtain a homogeneous blend. The mixture was cooled to $40{ }^{\circ} \mathrm{C}$ and $20 \mathrm{~g}$ of the solution mixture, $0.13 \mathrm{~g} / \mathrm{cm}^{2}$, was weighed and placed in polystyrene petri plates and dried in an oven with air circulation (Model B5AFD, Mark DeLeo) at $35^{\circ} \mathrm{C}$ for $20 \mathrm{~h}$. The films obtained were stored ( $58 \% \mathrm{UR}, 25^{\circ} \mathrm{C}$ ) in desiccators containing a saturated solution of magnesium nitrate for $48 \mathrm{~h}$ before being characterized.

\subsection{Film characterization}

The safflower oil capsule waste-corn starch films were characterized by determining thickness and mechanical properties.

\section{Film thickness measurement}

Thickness of the films was measured using a digital micrometer (Model MDC-25, Mitutoyo Corp. Tokyo, Japan) with a precision of $0.001 \mathrm{~mm}$. The thickness of each type of film was determined from an average of three films, carried out at five different positions in each film specimen.

\section{Mechanical properties}

The mechanical properties [tensile strength $(\mathrm{MPa})$, elongation at break (\%) and Young's modulus ( $\mathrm{MPa})$ ] were determine using a Texture analyzer (TA.XT2i e Stable Micro Systems, UK) with a load cell of $5 \mathrm{~kg}$, using the A/TGT self-tightening roller grips fixture, according to ASTM D882-09 (American Society for Testing and Materials, 2009). Film specimen strips (80 mm-25 mm) were cut and their thickness was measured using a micrometer at three random positions along each strip. Ten strips were cut, and each one was held between the grips of the equipment for testing with the initial distance between the grip and test speed set to $50 \mathrm{~mm}$ and $0.8 \mathrm{~mm} \mathrm{~s}^{-1}$, respectively. Tensile strength (TS) and elongation at break (E) were determined directly from the stress-strain curves, and the YM was calculated as the slope of the initial linear portion of this curve.

\subsection{Statistical analysis}

Experiments were run in triplicate. Data were subjected to analysis of variance (ANOVA) and Tukey's test at a significance level of 0.05 using the software Statistica 12.0 (Statsoft Inc., São Paulo, Brazil).

\section{Results and discussion}

\subsection{Film thickness measurement}

Thickness of safflower oil capsule waste-corn starch films ranged between 0.105 to $0.158 \mathrm{~mm}$ (Table 1). Films with the lowest concentration of safflower oil capsule waste (20:4), showed less thickness differing significantly from the others. The compositions 30:4, 40:4 and 50:4 presented similar thickness. Valderrama \& Gante (2014) found similar values (0.193 to 0.201) for films based on blue corn flour with glycerol. Chambi \& Grosso (2011) evaluated biodegradable films based on methylcellulose, glucomannan, pectin and gelatin and obtained lower values for thickness ( 0.01 to $0.02 \mathrm{~mm}$ ). The values obtained in this study, indicate that the films have a suitable thickness for application in food packaging, to be resistant and flexible, except the film with lower concentration of gelatin, which showed higher stiffness, due to the lower concentration of glycerol.

Table 1. Film thickness, tensile strength (TS), elongation at break (E) and Young's Modulus (YM) of safflower oil capsule waste-corn starch films.

\begin{tabular}{|c|c|c|c|c|}
\hline $\begin{array}{c}\text { Film (safflower oil capsules } \\
\text { waste:corn starch) }\end{array}$ & Thickness (mm) & TS (MPa) & E (\%) & YM (MPa) \\
\hline $20: 4$ & $0.105 \pm 0.00^{b}$ & $4.26 \pm 0.01^{\mathrm{a}}$ & $106.71 \pm 4.69^{d}$ & $768.91 \pm 7.02^{a}$ \\
\hline $30: 4$ & $0.134 \pm 0.00^{\mathrm{a}}$ & $3.46 \pm 0.13^{\mathrm{b}}$ & $142.77 \pm 0.87^{\mathrm{c}}$ & $500.08 \pm 1.78^{\mathrm{b}}$ \\
\hline $40: 4$ & $0.135 \pm 0.01^{\mathrm{a}}$ & $3.12 \pm 0.06^{c}$ & $169.21 \pm 1.94^{\mathrm{b}}$ & $457.10 \pm 1.78^{c}$ \\
\hline $50: 4$ & $0.158 \pm 0.02^{\mathrm{a}}$ & $2.54 \pm 0.09^{\mathrm{d}}$ & $194.18 \pm 3.80^{\mathrm{a}}$ & $457.73 \pm 2.67^{c}$ \\
\hline
\end{tabular}

The results are represented as the means \pm standard deviation. Values with the same letter are not significantly different $(\mathrm{p}>0.05)$. 


\subsection{Mechanical properties}

The interaction of protein, hydrocolloids and other additives including water, plasticizers, can influence the mechanical properties of the films. Moreover, the protein chain and plasticizers played an important role in mechanical properties in these interactions (Park et al., 2001). Tensile strength (TS), elongation at break (E) and Young's Modulus (YM) of prepared films are shown in Table 1. Corn starch contains a higher content of amylose and lower content of amylopectin than cassava starch (Mali et al., 2004), which makes these films more resistant to moisture and less flexible than films made from cassava starch. The addition of a higher concentration of safflower oil capsule waste significantly changed film properties, due their higher content of gelatin and glycerol, which increased the elongation, and thus decreased the tensile strength. In all formulations, the presence of gelatin significantly reduced the TS as a result of the interaction between hydroxyl groups between protein and starch that may reduce the interaction between starch chains (Al-Hassan \& Norziah, 2012). Al-Hassan \& Norziah (2012) found low values for TS sago starch-gelatin films (1.28 to $1.70 \mathrm{MPa})$. Valderrama \& Gante (2014) found similar values of TS (2.76 to $5.34 \mathrm{MPa})$ for films based on blue corn flour with glycerol and also observed that the increase in glycerol content decreased the tensile strength. Polysaccharides and protein-polysaccharides based films with glycerol are more stretchable and flexible due to the plasticization effect that increases the mobility of polymer chains (Valderrama \& Gante, 2014). The values obtained were higher than the value found for polypropylene films (60\%) (Krochta \& DeMulder, 1997).

Film elongation at break is related to flexibility and the elongation capacity of the materials. The elongation was significantly higher for films with higher concentrations of waste (gelatin and glycerol). Chiumarelli \& Hubinger (2014) observed an increase in elongation at break (17.67 to 31.07 ) when the content of glycerol was increased for films formulated with cassava starch, glycerol, carnauba wax and stearic acid. Alvarado et al. (2015) evaluated blend films of chitosan, fish gelatin and transglutaminase and also observed that the films with higher content of fish gelatin resulting in increasing of elongation at break. Flexibility increase as a function of plasticizer content may be related to structural changes in the starch network because the matrix becomes less dense and, under tension, the movements of the polymer chains are facilitated. The elongation at break was significantly higher in the formulation 50:4, indicating more flexibility, but with sufficient tensile strength to protect food. The films showed higher values than polyvinylidene chloride (20-40\%) (Gennadios et al., 1994) that is used principally in clear, flexible, and impermeable plastic food wrap.

The Young's modulus indicate the rigidity of the film, a higher value corresponds to a more rigid material (Pelissari et al., 2012). The film 20:4 showed higher values for Young's Modulus indicating that this film has more rigidity. The formulations 30:4, 40:4 and 50:4 showed lower values, thus presenting less rigidity and greater elasticity, but no had differences of the formulations 40:4 and 50:4.

Higher TS and lower E\%, results in higher Young's Modulus, and generally Young's Modulus increased with a decrease in protein content (Al-Hassan \& Norziah, 2012). In this study
Young's Modulus significantly decreased with incorporation of safflower oil capsule waste in all films. Al Hassan \& Norziah (2012) also noted a significant decrease in the Young's Modulus with incorporation of fish gelatin in sago starch-gelatin edible films.

\section{Conclusion}

The results demonstrated that the nutraceutical capsule waste can be blended with corn starch to form films with different characteristics. Safflower oil capsule waste: corn starch formulations with ratios of 40:4 and 50:4 appear to form good flexible films, however, the formulations 20:4, 30:4 and 40:4 showed films that were more resistant. The results showed that different ratios of safflower oil capsule waste affected mechanical properties of the films. Changing the ratio of one polymer, as in this study, where the proportions of safflower oil capsules wastes were modified, it is possible to modify the tensile strength and extensibility of the composite films.

The addition of safflower oil capsule waste in corn starch films is potentially a viable alternative for the packaging industry due to the recovery of waste and the subsequent production of biodegradable films that are more expandable in applications among different foods.

\section{Acknowledgements}

The authors are thankful to Laboratory Chemical Pharmaceutical Tiaraju, located in Santo Angelo - RS, for supplying raw material for this research and to Coordenação de Aperfeiçoamento de Pessoal de Nível Superior (CAPES) and Fundação de amparo à pesquisa no estado do Rio Grande do Sul (FAPERGS) for the financial support.

\section{References}

Al-Hassan, A. A., \& Norziah, M. H. (2012). Starch-gelatin edible films: water vapor permeability and mechanical properties as affected by plasticizers. Food Hydrocolloids, 26(1), 108-117. http://dx.doi. org/10.1016/j.foodhyd.2011.04.015.

Alvarado, S., Sandoval, G., Palos, I., Tellez, S., Aguirre-Loredo, Y., \& Velazguez, G. (2015). The effect of relative humidity on tensile strength and water vapor permeability in chitosan, fish gelatin and transglutaminase edible films. Food Science and Technology, 35(4), 690-695.

American Society for Testing and Materials - ASTM. (2009). Designation D882-09: standard test method for tensile properties of thin plastic sheeting. Philadelphia: ASTM. Annual book of ASTM standards.

Bodini, R. B., Sobral, P. J. A., Favaro-Trindade, C. S., \& Carvalho, R. A. (2013). Properties of gelatin-based films with added ethanol-propolis extract. LWT - Food Science and Technology, 51(1), 104-110. http:// dx.doi.org/10.1016/j.lwt.2012.10.013.

Cao, N., Fu, Y., \& He, J. (2007). Preparation and physical properties of soy proteinisolate and gelatin composite films. Food Hydrocolloids, 21(7), 1153-1162. http://dx.doi.org/10.1016/j.foodhyd.2006.09.001.

Chambi, H. N. M., \& Grosso, C. R. F. (2011). Mechanical and water vapor permeability properties of biodegradables films based on methylcellulose, glucomannan, pectin and gelatin. Food Science and Technology, 31(3), 739-746. http://dx.doi.org/10.1590/S010120612011000300029. 
Chiumarelli, M., \& Hubinger, M. D. (2014). Evaluation of edible films and coatings formulated with cassava starch, glycerol, carnauba wax and stearic acid. Food Hydrocolloids, 38, 20-27. http://dx.doi. org/10.1016/j.foodhyd.2013.11.013.

Emiroğlu, Z. K., Yemiş, G. P., Coşkun, B. K., \& Candoğan, K. (2010). Antimicrobial activity of soy edible films incorporated with thyme and orégano essential oils on fresh ground beef patties. Meat Science, 86(2), 283-288. http://dx.doi.org/10.1016/j.meatsci.2010.04.016. PMid:20580990.

Famá, L., Gerschenson, L., \& Goyanes, S. (2009). Starch-vegetable fibre composites to protect food products. Carbohydrate Polymers, 75(2), 230-235. http://dx.doi.org/10.1016/j.carbpol.2008.06.018.

Flieger, P., Kantorová, M., Prell, H., Rezanka, M., \& Votruba, L. (2003). Biodegradable plastics from renewable sources. Folia Microbiologica, 48(1), 27-44. http://dx.doi.org/10.1007/BF02931273. PMid:12744074.

Gennadios, A., McHugh, T. H., Weller, C. L., \& Krochta, J. M. (1994). Edible coatings and films based on proteins. In J. M. Krochta, E. A. Baldwin \& M. Nisperos-Carriedo (Eds.), Edible films and coatings to improve food quality (pp. 201-277). Lancaster: Technomic Publishing Company.

Krochta, J. M., \& DeMulder, C. L. C. (1997). Edible and biodegradable polymer films: Challenges and opportunities. Food Technology, 51, 60-74.

Mali, S., Karam, L. B., Ramos, L. P., \& Grossmann, M. V. (2004). Relationships among the composition and physicochemical properties of starches with lthe characteristics of their films. Journal of Agricultural and Food Chemistry, 52(25), 7720-7725. http://dx.doi. org/10.1021/jf049225+. PMid:15675825.
Ou, S., Wang, Y., Tang, S., Huang, C., \& Jackson, M. G. (2005). Role of ferulic acid inpreparing edible films from soy protein isolate. Journal of Food Science, 35, 205-210.

Park, S. K., Rhee, C. O., Bae, D. H., \& Hettiarachchy, N. S. (2001). Mechanical properties and water-vapor permeability of soy-protein films affected by calciumsalts and glucono-delta-lactone. Journal of Agricultural and Food Chemistry, 49(5), 2308-2312. http://dx.doi. org/10.1021/jf0007479. PMid:11368594.

Pelissari, F. M., Yamashita, F., García, M. A., Martino, M. N., Zaritzky, N. E., \& Grossmann, M. V. E. (2012). Constrained mixture design applied to the developmentof cassava starch-chitosan blown films. Journal of Food Engineering, 108(2), 262-267. http://dx.doi. org/10.1016/j.jfoodeng.2011.09.004.

Prodpran, T., Benjakul, S., \& Artharn, A. (2007). Properties and microstructure ofprotein-based film from round scad (Decapterus maruadsi) muscle as affected by palm oil and chitosan incorporation. International Journal of Biological Macromolecules, 41(5), 605-614. http://dx.doi.org/10.1016/j.ijbiomac.2007.07.020. PMid:17868827.

Simkovic, I. (2013). Unexplored possibilities of all-polysaccharide composites. Carbohydrate Polymers, 95(2), 697-715. http://dx.doi. org/10.1016/j.carbpol.2013.03.040. PMid:23648032.

Valderrama, A. C. V., \& Gante, C. R. (2014). Development of biodegradable films based on blue corn flour with potential applications in food packaging: effects of plasticizers on mechanical, thermal, and microstructural properties of flour films. Journal of Cereal Science, 60(1), 60-66. http://dx.doi.org/10.1016/j.jcs.2014.01.015.

Wu, M., Wang, L., Li, D., Mao, Z., \& Adhikari, B. (2013). Effect of flaxseed meal on the dynamic mechanical properties of starch-based films. Journal of Food Engineering, 118(4), 365-370. http://dx.doi. org/10.1016/j.jfoodeng.2013.04.017. 